\title{
Economic comparison of aerial and ground ignition for rangeland prescribed fires
}

\author{
G. ALLEN RASMUSSEN, GUY R. MCPHERSON, AND HENRY A. WRIGHT
}

\section{Abstract}

Average ignition costs per ha for aerial and ground iznited preseribed burns in redberry juniper (Juniperus pinchotil)-mixed grass communities were compared to determine the feasibility of using aerial ignition on rangelands. Aerial ignition techniques had greater total costs than ground ignition because of higher fixed costs. However, if greater than 4,000 ha could be burned, as a single or multiple unit, aerial ignition costs are $\$ 1.36 /$ ha less than estimated ground ignition costs.

Key Words: fireline costs, average costs, redberry juniper-mixed grass, Juniperus pinchotii

Increased use of prescribed fire for natural resource management has resulted in a variety of ignition techniques for the implementation of prescribed fire. Ignition techniques can be classified into 2 categories, aerial and ground ignition. Aerial ignition technology has advanced so that the gellied-gasoline helitorch (dispenses gellied-gasoline through a pump assembly carried by a helicopter) and the aerial ignition device (which uses plastic spheres filled with potassium permanganate and ethylene glycol) are common ignition sources (Jukkala 1984). Both are being continually refined as they are tested on the many fuel types and conditions found in natural resource management. The most extensive work has been conducted in forests on prescribed fires and wildfires. Ground ignition is any type of ignition technique which is performed from the ground. Techniques range in sophistication from the fire rake to the vehicle-mounted terra torch (dispenses gellied gasoline through a high pressure pump placed in a truck). Most common, however, is the drip torch which uses a gasoline and diesel mixture as an ignition source.

Comparisons of aerial and ground ignition have been restricted to mechanical and functional aspects. For example, aerial ignition offers greater ignition speed and increased safety to ground personnel compared to ground ignition in specific cases (Mathews 1984). Economic considerations have received little attention.

The objective of this study was to compare aerial and ground ignition in redberry juniper (Juniperus pinchotii Sudw.)-mixed grass communities in western Texas. This study was conducted concurrently with another study to determine if the helitorch could meet prescribed fire objectives in this fuel type.

\section{Materials and Methods}

The dominant vegetation type on all units was redberry junipermixed grass. Herbaceous vegetation was dominated by little bluestem (Schizachyrium scoparium [Michx.] Nash.), buffalograss (Buchloe dactyloides [Nutt.] Engelm.), tobosagrass (Hilaria mutica [Buckl.] Benth.), and sideoats grama (Bouteloua curtipendula [Michx.] Torr.). All units had been chained or individually tree dozed to reduce redberry juniper competition and allow herbace-

\footnotetext{
Authors are former research assistants, Department of Range and Wildlife Management, Texas Tech University, Lubbock 79409; and Horn Professor, Department of Range and Wildlife Management, Texas Tech University. Senior author currently with Vegetation Management Consultants, 4702 4th $\$ 240$, Lubbock, Texas 79416. Article is contribution No. T-9-493 of the College of Agricultural Sciences, Texas Tech University.

The authors wish to acknowledge R.A. Masters, the numerous students who assisted on the prescribed burns used in this study, and the helitorch contractor, Jimmy Propst of Propst Helicopters.

Manuscript accepted 24 March 1988.
}

ous production to increase. Mechanical treatments occurred from 3 to $15 \mathrm{yr}$ before burning. This vegetation type is considered volatile, so most units were burned using a two-stage technique. Firelines were $125 \mathrm{~m}$ wide and were burned out using ground ignition techniques for safety considerations. The two-stage ignition technique used to burn this community type has been described previously (Wright and Bailey 1982 , McPherson et al. 1986, Rasmussen et al. 1986). One aerial and one ground ignition unit were burned in one stage.

Costs associated with prescribed burning can vary greatly, depending on fuel type and how costs are determined (Lionberger 1984). Other variables within a fuel type which cause costs to vary include weather, fuel loads and continuity, existing fuel breaks, and topography. To reduce cost variability, economic comparisons were restricted to prescribed fires in redberry juniper-mixed grass habitat conducted between 1983 and 1986 by the Texas Tech University Department of Range and Wildlife Management for research and training purposes. Burns were classified by their source of ignition of the main unit (aerial or ground; firelines for all units were ground-ignited).

A survey by the authors indicated the helitorch is the most commonly available and widely used aerial ignition system in the United States, so it was selected for use in this study, though no aerial ignition system is available in western Texas. Aerial ignition with a helitorch was used on 6 units ranging from 659 to 4,014 ha. Organizational procedures for aerially ignited units followed Masters et al. (1986). Ground ignition was conducted on 5 units ranging from 142 to 964 ha. Preburned firelines were not used on the 142 ha unit. Drip torches were used for ground ignition because they are the most commonly used and available to prescribd fire practitioners. The ignition pattern for both techniques varied depending on the burn objectives, topography, and fine fuel loads.

Data obtained from each burn included number of personnel and assignments, distance traveled from Lubbock, Texas, hours of tracklaying tractor work needed to prepare the mineral soil lines, and drip torch and helitorch fuel needed. Costs are expressed in 1986 dollars. Only actual direct burning costs were included in this analysis. Pasture deferment and overhead costs were not included.

In the redberry juniper fuel type, preparation procedures are identical for both aerial and ground ignition techniques. Therefore, costs were separated into average preparation costs (APC) for all burns, and average ignition costs (AIC) for aerial and ground ignited units. Preparatory costs included reconnaissance, construction of mineral soil lines, and fireline burning costs. Ignition costs included only the labor, fuel, maintenance, and transportation costs that occurred during ignition of the main unit. For aerial ignition the costs of the helitorch and its required fuel was also included.

Since all burns were conducted for teaching and research, personnel costs were estimated by paying the fire boss $\$ 500.00 /$ day, and other personnel $\$ 50.00 /$ day. Vehicle costs were obtained by charging $\$ 0.31 / \mathrm{km}$ for four-wheel drive vehicles and $\$ 0.28 / \mathrm{km}$ for two-wheel drive vehicles. Drip torch fuel (70:30 ratio of diesel and gasoline) cost was $\$ 0.26 / 1$. The tracklaying tractor $(0.104 \mathrm{MW})$ equipped with a bulldozer blade was rented for $\$ 55.00 / \mathrm{hr}$, which included the rental of the tractor and operator wages. Maintenance cost on equipment other than vehicles was estimated at $\$ 25.00 /$ burn- 
Table 1. Coats incurred during preparation of 125-m wide firelines for preseribed burning redberry juniper-mired grass rangeland.

\begin{tabular}{|c|c|c|c|c|c|c|c|c|c|}
\hline \multirow{2}{*}{$\begin{array}{l}\text { Unit } \\
\text { size } \\
\text { (ha) }\end{array}$} & \multirow{2}{*}{$\begin{array}{c}\text { Total } \\
\text { fireline } \\
\text { length } \\
\text { (km) }\end{array}$} & \multirow{2}{*}{$\begin{array}{c}\text { Time } \\
\text { to } \\
\text { burn } \\
\text { (days) }\end{array}$} & \multicolumn{5}{|c|}{ Cost (\$) } & \multirow{2}{*}{$\begin{array}{l}\text { Total } \\
\text { cost } \\
(\$)\end{array}$} & \multirow{2}{*}{$\begin{array}{c}\operatorname{cost} \\
(\$ / \mathbf{k m})\end{array}$} \\
\hline & & & Labor ${ }^{1}$ & Trans. ${ }^{2}$ & Tractor $^{3}$ & Fuel $^{4}$ & Eq. ${ }^{5}$ & & \\
\hline $\begin{array}{r}223 \\
311 \\
364 \\
648 \\
659 \\
769 \\
964 \\
1250 \\
1417 \\
1417 \\
3715 \\
4014\end{array}$ & $\begin{array}{r}2.08 \\
4.31 \\
5.27 \\
2.40 \\
5.11 \\
7.19 \\
7.19 \\
8.15 \\
8.62 \\
8.62 \\
9.74 \\
19.80\end{array}$ & $\begin{array}{l}2 \\
2 \\
2 \\
1 \\
1 \\
2 \\
2 \\
4 \\
2 \\
2 \\
3 \\
5\end{array}$ & $\begin{array}{r}1800 \\
1800 \\
1800 \\
800 \\
950 \\
1600 \\
1900 \\
3550 \\
1600 \\
1800 \\
2700 \\
5000\end{array}$ & $\begin{array}{r}560 \\
896 \\
550 \\
285 \\
342 \\
570 \\
896 \\
896 \\
660 \\
660 \\
1146 \\
2156\end{array}$ & $\begin{array}{r}292 \\
369 \\
120 \\
369 \\
292 \\
369 \\
440 \\
369 \\
880 \\
589 \\
732 \\
2932\end{array}$ & $\begin{array}{r}50 \\
40 \\
75 \\
25 \\
131 \\
62 \\
50 \\
50 \\
65 \\
115 \\
192 \\
233\end{array}$ & $\begin{array}{r}50 \\
50 \\
50 \\
25 \\
25 \\
50 \\
50 \\
100 \\
50 \\
50 \\
75 \\
125\end{array}$ & $\begin{array}{r}2752 \\
3155 \\
2595 \\
1504 \\
1740 \\
2651 \\
3336 \\
4965 \\
3255 \\
3214 \\
4845 \\
10446\end{array}$ & $\begin{array}{r}1323.08 \\
732.02 \\
492.41 \\
626.87 \\
340.51 \\
368.71 \\
463.98 \\
609.20 \\
377.61 \\
372.85 \\
497.43 \\
527.58\end{array}$ \\
\hline
\end{tabular}

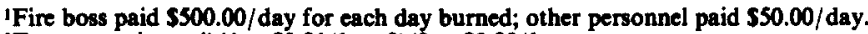

${ }^{2}$ Transportation $-4 \times 4$ at $\$ 0.31 / \mathrm{km}, 2 \times 2$ at $\$ 0.28 / \mathrm{km}$.

${ }^{3}$ Track laying tractor $(0.104 \mathrm{MW})$ with operator at $\$ 55.00 / \mathrm{hr}$.

Drip torch fuel at $\$ 0.26 / 1$.

SMaintenance for miscellaneous equipment at \$25.00/day.

ing day. This estimate was obtained by summing maintenance costs from 1983 through 1986, and dividing by the number of burn-days.

One reconnaissance trip was included in the preparation costs on all burns. The reconnaissance trip ensured correct placement of mineral soil lines and provided details for the fire plan. The cost of this trip was $\$ 500.00 /$ day for the fire boss and $\$ 50.00 /$ day for other personnel ( 1 to 4 depending on unit size) plus transportation. Trips taken to the burn unit but canceled due to inappropriate weather were included as part of the cost of preparation or ignition depending on when they occurred.

Use of the helitorch required additional support personnel including an aerial ignition boss, helipad boss, and suppression crew boss all at $\$ 150.00 /$ day. In addition, a 3-person helipad crew (3) was needed at $\$ 50.00 /$ day per person. Suppression crews were divided into 2 crews ranging in size from 2 to 6 people. These crews moved in conjunction with the helitorch depending on the ignition pattern.

The helitorch contractor estimated the cost of using the helitorch on individual units at $\$ 9.88 /$ ha for 1,000 ha, $\$ 4.94 /$ ha for 2,000 ha, and $\$ 2.47 /$ ha for 4,000 ha. No further decrease in helitorch costs occurred if more than 4,000 ha were to be burned. Contracted cost included the helicopter, pilot, helicopter fuel, helitorch, and thickening agent for the helitorch fuel. Gasoline for the helitorch was purchased at an average cost of $\$ 0.26 /$ liter.

Ground ignited headfires were ignited with ignition crews of 2 to 8 personnel depending on ignition pattern. One unit, burned to improve wildlife habitat, consisted of several segments ranging in size from 3 to 24 ha. A single mineral soil fire line was placed around each segment, which was then burned using a strip-headfire technique in a single stage. All other units consisted of a single segment and were ignited using a single headfire technique, with preburned firelines.

Summary statistics (means and standard errors) were determined for fireline preparation and headfire costs. Regression analysis was used to determine the effect of unit size on APC and AIC per ha for aerial and ground ignition. Total average costs were determined by summing APC and AIC regression equations.

\section{Results and Discussion}

Units can be burned without preburned firelines under specific conditions. However, firelines were used on most burns in this study to reduce the risk associated with prescribed burning. Average cost of installing these firelines and other preparatory operations (reconnaissance, constructions of mineral soil lines) was expressed as a logarithmic function (Fig. 1). Decreasing slope indicated an economy of size between the cost of preparing a unit to be burned and its size. The major source of variation in preparatory costs was attributed to burning firelines. When preparation costs are divided into individual categories, labor accounted for 56 $\pm 9.17 \%$ of the costs to burn out the fireline (Table 1). Unit shape as well as size influenced the length of fireline needed to prepare a unit to be burned. Time required to burn out firelines depended on

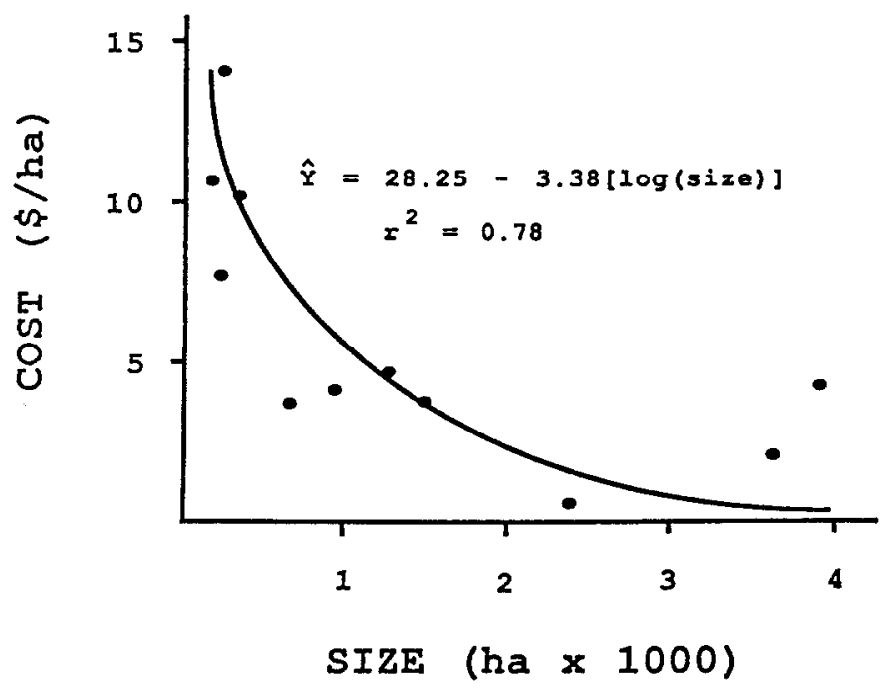

Fig. 1. Relationship between unit size and average preparation costs for prescribed burns conducted between 1983 and 1986 in a volatile fuel type (redberry juniper-mixed grass) near Lubbock, Texas. These costs include reconnaissance, mineral soil line preparation, and burning firelines.

weather, fine fuel characteristics, topography, availability of existing fuel breaks and unit size.

The relationship between unit size and $\mathrm{AIC} /$ ha for aerial ignition was logarithmic (Fig. 2). No significant $(P \leq 0.05)$ relationship was found between unit size and average ignition costs using ground ignition.

The sum of APC and AIC for ground and aerial ignited prescribed fires indicated similar trends for total average costs curves (Fig. 3). Factors affecting total average cost were the same as those previously discussed for burning firelines. Units larger than 1,000 ha are rarely burned using ground ignition because these problems 


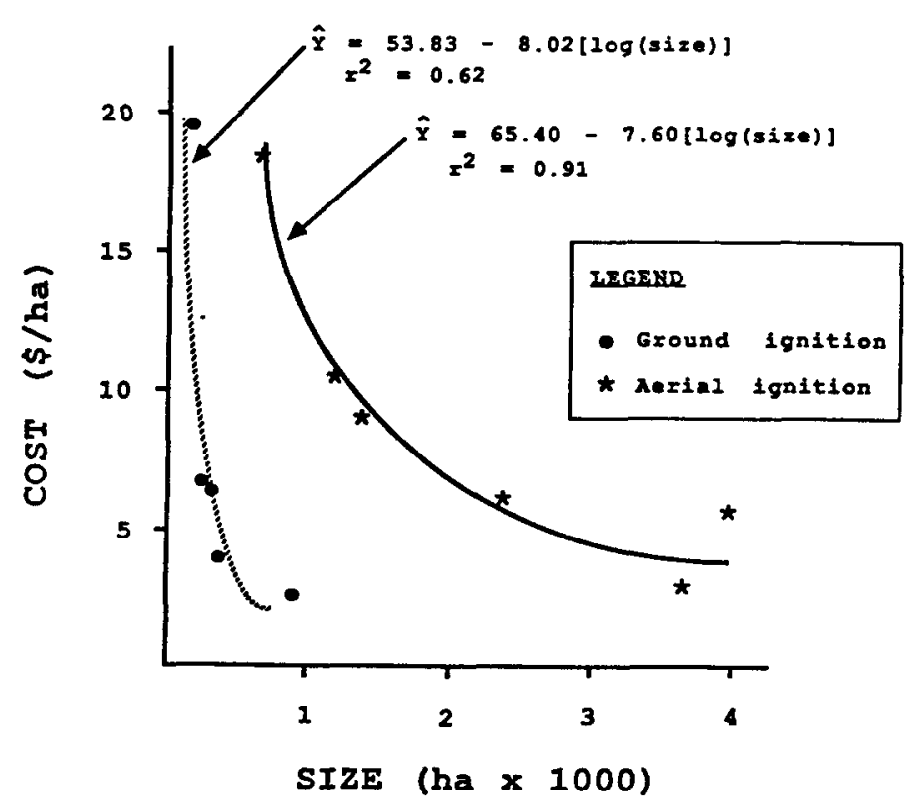

Fig. 2. Relationship between unit size and average ignition cost for aerial and ground ignited prescribed burns conducted between 1983 and 1986 on a volatile fuel type (redberry juniper-mixed grass) near Lubbock, Texas.

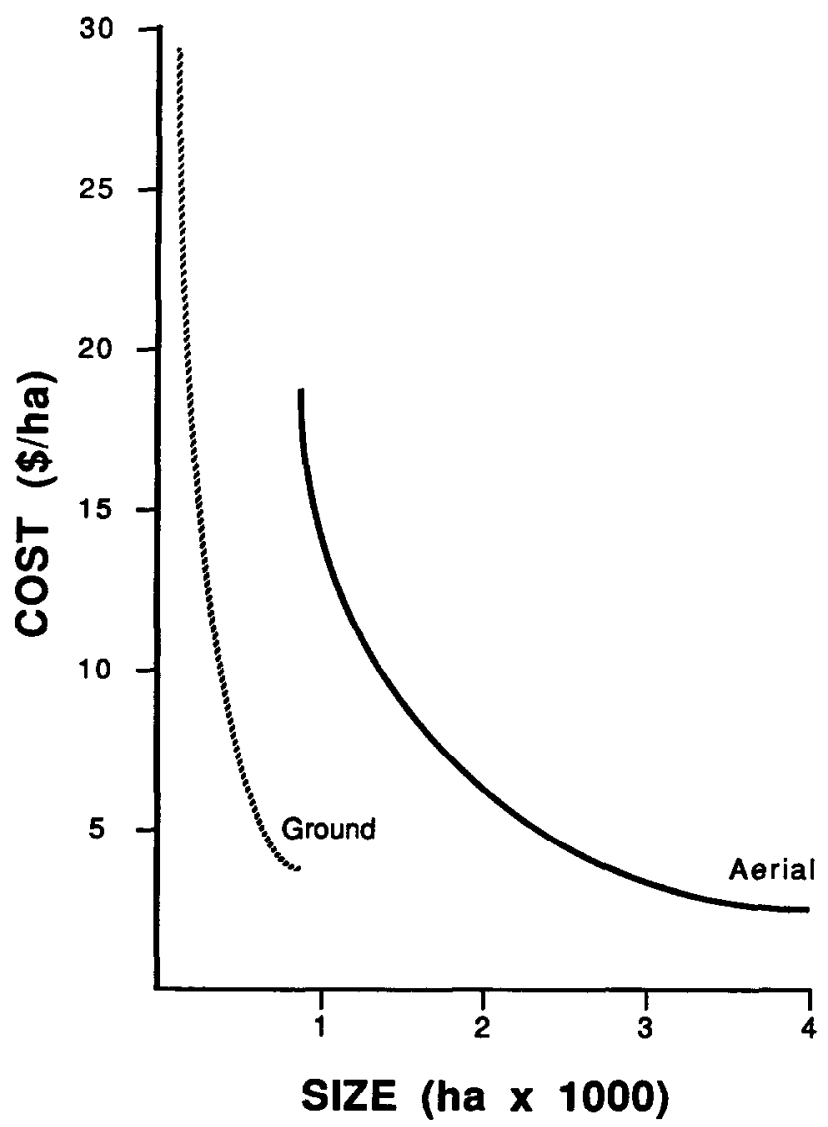

Fig. 3. Relationship between unit size and total average ignition cost (sum of $A P C+A I C$ regression lines) for aerial and ground ignited prescribed burns.

increase time required for ignition and decrease the probability that burn objectives can be met.

Before the helitorch became available, the largest unit attempted by the Texas Tech University research burning program was 964 ha. Larger units were not attempted because of labor and time requirements needed to complete these burns in the redberry juniper-mixed grass fuel type. For example, the largest unit ignited with the helitorch required 70 man-hours. It was estimated that 600 man-hours would be required to burn the same unit using ground ignition because of the inordinate number of fuel breaks (roads, trails, and ridges) (Masters et al. 1986). A 10-person ignition crew would be the largest which could safely ignite the unit with available equipment. Thus ground ignition would require approximately 12 days and the estimated budgeted cost would be $\$ 1.36 /$ ha more than aerial ignition. This also assumes 12 burning days would occur during a single season. In western Texas, 12 days which are appropriate for headfire ignition rarely occur during 1 spring burning season.

Preparation costs accounted for an average of $22 \pm 3.4 \%$ of the total average costs on aerially ignited units and $61 \pm 1.3 \%$ on ground ignited units. Lower values for aerially ignited units were attributed to (1) increased cost of using the helitorch on the headfire phase of ignition, and (2) decreased distance of fireline per unit area on large units. Aerially ignited units in this study required an average of $0.0048 \mathrm{~km}$ of fireline per ha burned; ground-ignited units required an average of $0.0087 \mathrm{~km} / \mathrm{ha}$.

The helicopter and helitorch accounted for an average of $66 \pm$ $5.5 \%$ of the average total cost on aerially ignited units. A helitorch contractor is not available in western Texas. The contractor used in this study required $\$ 10,000$ to bring his helitorch to this area. If at least 4,000 ha could be burned as a single unit or in multiple units, the helitorch could be contracted for \$2.47/ ha. Helitorch costs probably can be reduced in areas closer to a helitorch contractor. The smaller aerially ignited units in this study burned as multiple units (contracted for the minimum cost of $\$ 2.47 / \mathrm{ha}$ ) had total average costs of $\$ 5.96 \pm 0.70 / \mathrm{ha}$. If small units are to be burned, the full economic advantage of aerial ignition can be realized only if burned in association with other units.

These data indicate aerial ignition is an economically feasible alternative for burning large units or groups of smaller units. These data do not indicate precisely at what size aerial ignition becomes less expensive than ground ignition. Aerial ignition offers a practical alternative on units larger than 1,000 ha since it allows these units to be burned with increased efficiency. The increased efficiency allows a greater number of hectares to be burned for the same average cost as ground ignition. However, aerial ignition loses its advantage in the presence of area or capital constraints. Cost curves for aerial ignition found in this study were strongly influenced by the contractor's price structure. A different price structure for using the helitorch could alter these conclusions.

\section{Literature Cited}

Jukkala, A.H. 1984. State-of-the-art in aerial ignition equipment in the USDA Forest Serv. p. 159-166. In: R.W. Mutch (Tech. Coord.) Prescribed fire by aerial ignition. Proc. Intermountain Fire Counc. Missoula, Mont.

Llonberger, B. 1984. Costs and operational problems in aerial ignition. p. 40-45. In: R.W. Mutch (Tech. Coord.) Prescribed fire by aerial ignition. Proc. Intermountain Fire Counc. Missoula, Mont.

Masters, R.M., G.A. Rasmussen, and G.R. McPherson. 1986. Prescribed burning with a helitorch on the Texas rolling plains. Rangelands 8:173-176.

Mathew, E.E. 1984. Range improvement in sagebrush-grassland with the helitorch. p. 86-90. In: R.W. Mutch (Tech Coord.) Prescribed fire by aerial ignition. Proc. Intermountain Fire Counc. Missoula, Mont.

MePherson, G.R., G.A. Rasmuseen, H.A. Wright, and C.M. Britton. 1986. Getting started in prescribed burning. Texas Tech Univ. Dept. Range and Wildl. Manage. Note 10.

Rasmusen, G.A., G.R. MePherson, and H.A. Wright. 1986. Prescribed burning juniper communities in Texas. Texas Tech Univ. Dept. Range and Wildl. Manage. Note 9.

Wright, H.A., and A.W. Balley. 1982. Fire ecology: United States and southern Canada. John Wiley \& Sons, New York. 